medRxiv preprint doi: https://doi.org/10.1101/2020.09.11.20192690; this version posted March 11, 2021. The copyright holder for this preprint (which was not certified by peer review) is the author/funder, who has granted medRxiv a license to display the preprint in perpetuity.

It is made available under a CC-BY-NC-ND 4.0 International license .

TITLE: Characteristics of anti-SARS-CoV-2 antibodies in recovered COVID-19 subjects.

RUNNING TITLE: SARS-CoV-2 antibodies in recovered COVID-19 subjects.

AUTHOR LIST:

Huynh, Angela ${ }^{1}$; Arnold, Donald M. ${ }^{1,2}$; Smith, James W. ${ }^{1}$; Moore, Jane C. ${ }^{1}$; Zhang, Ali ${ }^{3,4,5}$;

7 Chagla, Zain ${ }^{1,6}$; Harvey, Bart J. ${ }^{7,8}$; Stacey, Hannah D. ${ }^{3,4,5}$; Ang, Jann C. ${ }^{3,4,5}$; Clare, Rumi ${ }^{1}$; Ivetic,

8 Nikola ${ }^{1}$; Chetty, Vasudhevan T. ${ }^{9}$; Bowdish, Dawn ME ${ }^{1,3,4}$; Miller, Matthew S. ${ }^{3,4,5}$; Kelton, John

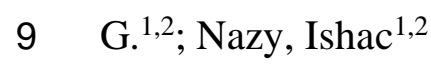

AFFILIATE INSTITUTIONS:

$12{ }^{1}$ Department of Medicine, Michael G. DeGroote School of Medicine, McMaster University,

13 Hamilton, Ontario, Canada; ${ }^{2}$ McMaster Centre for Transfusion Research, Hamilton, Ontario,

14 Canada; ${ }^{3}$ Michael G. DeGroote Institute for Infectious Disease Research, Hamilton, Ontario,

15 Canada; ${ }^{4}$ McMaster Immunology Research Centre, Hamilton, Ontario, Canada; ${ }^{5}$ Department of

16 Biochemistry and Biomedical Sciences, McMaster University, Hamilton, Ontario, Canada;

$17{ }^{6}$ Division of Infectious Diseases, Department of Medicine, McMaster University, Hamilton,

18 Ontario, Canada; ${ }^{7}$ Hamilton Public Health Services, Hamilton, Ontario, Canada; ${ }^{8}$ Dalla Lana

19 School of Public Health, University of Toronto, Toronto, Ontario, Canada; ${ }^{9}$ HRLMP McMaster

20 University, St Joseph's Healthcare Hamilton, Hamilton, ON, Canada 
medRxiv preprint doi: https://doi.org/10.1101/2020.09.11.20192690; this version posted March 11, 2021. The copyright holder for this preprint (which was not certified by peer review) is the author/funder, who has granted medRxiv a license to display the preprint in perpetuity.

It is made available under a CC-BY-NC-ND 4.0 International license .

\section{CORRESPONDENCE AUTHOR(S):}

23

24

25

26

27

28

29

30

$31 \quad$ Abstract word count: 200

32 Main text word count: 3487

33 Table and Figures: 2 Tables and 4 Figures

34 References: 47
Ishac Nazy, PhD

HSC 3H53

1280 Main Street West

Hamilton, ON, Canada L8S 4K1

Tel: (905) 525-9140 x20242

Fax: (905) 529-6359

Email: nazii@mcmaster.ca

35 
medRxiv preprint doi: https://doi.org/10.1101/2020.09.11.20192690; this version posted March 11, 2021. The copyright holder for this preprint (which was not certified by peer review) is the author/funder, who has granted medRxiv a license to display the preprint in perpetuity.

It is made available under a CC-BY-NC-ND 4.0 International license .

Abstract:

37 Coronavirus Disease 2019 (COVID-19) is a global pandemic caused by the novel severe acute

38 respiratory syndrome coronavirus 2 (SARS-CoV-2). While detection of SARS-CoV-2 by

39 polymerase chain reaction with reverse transcription (RT-PCR) is currently used to diagnose

40 acute COVID-19 infection, serological assays are needed to study the humoral immune response

41 to SARS-CoV-2. SARS-CoV-2 IgG/A/M antibodies against SARS-CoV-2 spike (S) protein and

42 its receptor-binding domain (RBD) were characterized using an enzyme-linked immunosorbent

43 assay (ELISA) and assessed for their ability to neutralize live SARS-CoV-2 virus in recovered

44 subjects who were RT-PCR-positive ( $\mathrm{n}=153$ ), RT-PCR-negative ( $\mathrm{n}=55$ ), and control samples

45 collected pre-COVID-19 ( $\mathrm{n}=520)$. Anti-SARS-CoV-2 antibodies were detected in $90.9 \%$ of

46 resolved subjects up to 180 days post-symptom onset. Anti-S protein and anti-RBD IgG titers

47 correlated $(r=0.5157$ and $r=0.6010$, respectively) with viral neutralization. Of the RT-PCR-

48 positive subjects, $22(14.3 \%)$ did not have anti-SARS-CoV-2 antibodies; and of those, 17 had

49 RT-PCR cycle threshold $(\mathrm{Ct})$ values $>27$, raising the possibility that these indeterminate results

50 are from individuals who were not infected, or had mild infection that failed to elicit an antibody

51 response. This study highlights the importance of serological surveys to determine population-

52 level immunity based on infection numbers as determined by RT-PCR.

53

54 Keyword: SARS-CoV-2, COVID-19, antibody, serology 
medRxiv preprint doi: https://doi.org/10.1101/2020.09.11.20192690; this version posted March 11, 2021. The copyright holder for this preprint (which was not certified by peer review) is the author/funder, who has granted medRxiv a license to display the preprint in perpetuity.

It is made available under a CC-BY-NC-ND 4.0 International license .

Introduction:

Coronavirus disease 2019 (COVID-19) is caused by the novel severe acute respiratory syndrome coronavirus 2 (SARS-CoV-2) [1]. Asymptomatic and pre-symptomatic virus

59 transmission is one of the biggest challenges with the global pandemic [2]. It is estimated up to $80 \%$ of people infected with COVID-19 have none or mild symptoms and asymptomatic

61 transmission accounts for half of all COVID-19 infections [3-5]. Approximately 20\% of

62 symptomatic infections are severe, disproportionately impacting the elderly and patients with

63 underlying health conditions $[6,7]$.

Laboratory diagnosis of COVID-19 is made using polymerase chain reaction with reverse transcription (RT-PCR) to detect viral mRNA from nasal or throat swabs [8-11]. Viral RNA is detectable as early as the first day of symptom onset and peaks within the first week of symptom onset [9]. The SARS-CoV-2 spike (S) protein, specifically the receptor-binding domain (RBD),

68 facilitates viral entry into the cell via the angiotensin-converting enzyme-2 (ACE2) receptor on 69 host cells [12-15]. Most people with a confirmed RT-PCR diagnosis of SARS-CoV-2 infection

70 develop IgG, IgA and IgM antibodies against S protein within 1-2 weeks of symptom onset and 71 continue to circulate after initial viral clearance [16-21].

73 detected in the circulation of greater than $90 \%$ of infected subjects by 10-11 days post-symptom

74 onset $[16,18,20,22]$. Virus-specific neutralizing antibodies, either induced through infection or

75 vaccination, can block viral infection [23]. Although antibodies may be generated against

76 multiple domains within the S protein, most neutralizing antibodies and highly potent

77 monoclonal antibodies target the RBD $[15,24]$. In this report, we profile the $\operatorname{IgG}, \operatorname{IgA}$, and $\operatorname{IgM}$

78 responses to the SARS-CoV-2 S protein and RBD in a cross-sectional serological study 
medRxiv preprint doi: https://doi.org/10.1101/2020.09.11.20192690; this version posted March 11, 2021. The copyright holder for this preprint (which was not certified by peer review) is the author/funder, who has granted medRxiv a license to display the preprint in perpetuity.

It is made available under a CC-BY-NC-ND 4.0 International license .

79 involving resolved COVID-19 infection. We also compared antibody levels with viral

80 neutralization and RT-PCR results.

\section{Methods and Materials:}

83 Study Design

84 Subjects who recovered from COVID-19 infection were identified by treating physicians, public

85 health officials and through hospital discharge databases that included hospitals in Hamilton,

86 Ontario, Canada (Hamilton General Hospital, Juravinski Hospital, McMaster University Medical

87 Centre, and St. Joseph's Healthcare). The study inclusion criteria were $\geq 18$ years of age, either

88 testing positive or negative for COVID-19 in the RT-PCR, with no exclusion criteria.

89 Participants with RT-PCR-positive results for SARS-CoV-2 and had since recovered (resolved

90 RT-PCR-positive, $\mathrm{n}=153$ ), and subjects who experienced symptoms but tested negative by RT-

91 PCR (RT-PCR-negative, $\mathrm{n}=55$ ) were included. Participants were interviewed by phone and self-

92 reported their age, sex, symptom onset date and RT-PCR test date and result. Pre-COVID-19

93 control samples were selected from healthy donors $(n=37)$ and samples sent for the ITP Registry

94 biobank from the McMaster Platelet Immunology Laboratory drawn prior to November 2019

95 (pre-COVID-19, $\mathrm{n}=483$ ) before documented local community transmission of SARS-CoV-2.

96 Serum was collected by venipuncture and cryopreserved until use. This study was approved by

97 the Hamilton Integrated Research Ethics Board (HIREB) and written informed consent was

98 obtained from all participants. 
medRxiv preprint doi: https://doi.org/10.1101/2020.09.11.20192690; this version posted March 11, 2021. The copyright holder for this preprint (which was not certified by peer review) is the author/funder, who has granted medRxiv a license to display the preprint in perpetuity.

It is made available under a CC-BY-NC-ND 4.0 International license.

100 A detailed protocol outlining protein production can be found in a study by Stadlbauer et al [25]

101 and is outlined in the Supplemental methods.

103 Microtitre well plates (384 wells, Nunc Maxisorp, Rochester, NY, USA) were coated with

$10425 \mu \mathrm{L} /$ well of S protein $(5 \mu \mathrm{g} / \mathrm{mL})$ or RBD $(2 \mu \mathrm{g} / \mathrm{mL})$ suspended in $50 \mathrm{mM}$ carbonate-bicarbonate

105 buffer ( $\mathrm{pH}$ 9.6). The plates were then blocked with $100 \mu \mathrm{L} / \mathrm{well}$ of $3 \%$ skim milk prepared in

106 phosphate buffered saline (PBS) with $0.05 \%$ Tween 20 at room temperature for 2-hours. The

107 blocking solution was removed, and diluted serum samples (1/100 prepared in 1\% skim milk in

108 PBS/0.05\% Tween 20) in technical duplicates were added to the plates and incubated for 1-hour

109 at room temperature. The plates were washed twice with PBS/0.05\% Tween 20 and thrice with

110 PBS. Bound human antibodies (IgG, IgA, or $\operatorname{IgM}$ ) were detected with $25 \mu \mathrm{L} /$ well of alkaline

111 phosphatase conjugated goat anti-human IgG ( $\gamma$-chain-specific, $1 / 2000$, Jackson

112 ImmunoResearch Laboratories, Inc, Westgrove, PA, USA), goat anti-human IgA ( $\alpha$-chain-

113 specific; 1/500, Jackson ImmunoResearch Laboratories, Inc, Westgrove, PA, USA) antibody, or

114 goat anti-human $\operatorname{IgM}$ ( $\mu$-chain-specific; 1/1000, Jackson ImmunoResearch Laboratories, Inc,

115 Westgrove, PA, USA) antibody prepared in PBS/0.05\% Tween 20 with 1\% skim milk. Plates

116 were washed as before and followed with the addition of $50 \mu \mathrm{L}$ substrate (4-

117 nitrophenylphosphate disodium salt hexahydrate in diethanolamine (MilliporeSigma, St. Louis,

118 MO, USA). The optical density (OD) was read at 405nm and 490nm (as a reference) measured

119 using a BioTek 800TS microplate reader (BioTek, Winooski, VT, USA). The assay cut-off was

120 determined as the mean and 3 standard deviations (SD) of the pre-COVID-19 control population.

121 Data are shown as a ratio of observed OD to the determined assay cut-off OD. OD ratio values

122 above 1 ratio were considered positive in the SARS-CoV-2 ELISA. Results for optimization of 
medRxiv preprint doi: https://doi.org/10.1101/2020.09.11.20192690; this version posted March 11, 2021. The copyright holder for this preprint (which was not certified by peer review) is the author/funder, who has granted medRxiv a license to display the preprint in perpetuity.

It is made available under a CC-BY-NC-ND 4.0 International license .

123 antigens, serum concentrations for the ELISA and its comparisons to commercially available

124 assays can be found in the Supplemental data.

125 PCR Cycle threshold (Ct) values of resolved COVID-19 samples

126 RT-PCR Ct values were retrieved from a subset of resolved subjects' original test date RT-PCR

127 ( $n=54)$. A detailed protocol of the in-house RT-PCR run by the Hamilton Regional Laboratory

128 Medicine Program virology lab is outlined in the Supplemental methods.

Detecting neutralizing antibodies for SARS-CoV-2

130 Vero E6 cells (ATCC CRL-1586) were seeded at a density of 2.5x10 cells per well in opaque 96

131 well flat-bottom plates (Costar) in complete DMEM (supplemented with 10\% FBS, 1\% L-

132 glutamine, 100U/ml penicillin-streptomycin). After 24-hours of incubation, serum (resolved and

133 RT-PCR-negative subjects) was inactivated by incubating at $56^{\circ} \mathrm{C}$ for 30 minutes, then diluted

134 1:10 in low serum DMEM (supplemented with 2\% FBS, 1\% L-glutamine, 100U/mL penicillin-

135 streptomycin), followed by a 1:2 dilution series in 96 well U-bottom plates resulting in a final

136 volume of $55 \mu \mathrm{L}$ diluted serum per well. An equal volume of SARS-CoV-2/SB3-TYAGNC

137 consisting of $330 \mathrm{PFU}$ per well was then added to the diluted serum and the serum-virus mixture

138 was incubated at $37^{\circ} \mathrm{C}$ for 1 -hour. Next, the Vero E6 culture media was then replaced with 100

$139 \mu \mathrm{L}$ of the serum-virus mixture and was incubated at $37^{\circ} \mathrm{C}$ for 72 -hours. The plates were read by

140 removing $50 \mu \mathrm{L}$ of culture supernatant and adding $50 \mu \mathrm{L}$ of CellTiter-Glo 2.0 Reagent (Promega,

$141 \mathrm{G} 9243$ ) to each well. The plates were then shaken at $282 \mathrm{cpm}$ at $3 \mathrm{~mm}$ diameter for 2-minutes,

142 incubated for 5-minutes at room temperature and luminescence was read using a BioTek

143 Synergy H1 microplate reader with a gain of 135 and an integration time of 1-second. Results are

144 expressed as geometric microneutralization titers at 50\% (MNT50). 
medRxiv preprint doi: https://doi.org/10.1101/2020.09.11.20192690; this version posted March 11, 2021. The copyright holder for this preprint (which was not certified by peer review) is the author/funder, who has granted medRxiv a license to display the preprint in perpetuity.

It is made available under a CC-BY-NC-ND 4.0 International license .

Statistical Analyses

146 Descriptive statistics were used to summarize the $\operatorname{IgG}$, $\operatorname{IgA}$, and $\operatorname{IgM}$ binding to S protein and

147 RBD as measured by mean OD across antigen and technical replicates. Differences between data

148 were tested for statistical significance using the paired or unpaired t-test and the Mann-Whitney

149 test. P-values are reported as 2-tailed. Correlations were calculated using standard Pearson

150 correlation. All statistical analyses were conducted using GraphPad Prism (version 7.0a,

151 GraphPad Software, San Diego, USA).

153 Results:

154 Study Demographics

155 Resolved (RT-PCR-positive, $\mathrm{n}=153$ ) samples were collected between 7-211 days post-symptom

156 onset. Median age of the resolved RT-PCR-positive subjects was 49 years (range: 18 - 82) and

15795 subjects (62.1\%) were female. COVID-19 negative subjects (RT-PCR-negative, $\mathrm{n}=55$ )

158 samples were collected between 7-246 days post-symptoms (Table 1). The median age of the

159 RT-PCR-negative subjects was 49 years (range: 20 - 89) and 39 (70.9\%) were female (Table 1).

160 Eleven (7.2\%) of the RT-PCR-positive resolved subjects and 37 (67.3\%) of the RT-PCR-

161 negative subjects were asymptomatic before testing.

162 Detecting SARS-CoV-2 antibodies in resolved COVID-19 subjects

163 To study the antibody response to SARS-CoV-2, we tested for IgG, IgA, and IgM antibodies to

164 the S protein and RBD in pre-COVID-19 controls ( $\mathrm{n}=520)$, resolved COVID-19 subjects

165 ( $\mathrm{n}=153)$, and RT-PCR-negative subjects $(\mathrm{n}=55)$. Pre-COVID-19 controls $(\mathrm{n}=520)$ were used to

166 determine the background reactivity to the $\mathrm{S}$ protein and RBD using samples from individuals 
medRxiv preprint doi: https://doi.org/10.1101/2020.09.11.20192690; this version posted March 11, 2021. The copyright holder for this preprint (which was not certified by peer review) is the author/funder, who has granted medRxiv a license to display the preprint in perpetuity.

It is made available under a CC-BY-NC-ND 4.0 International license.

167 drawn before COVID-19 (pre-November 2019). The cut-off was determined as the mean plus

168 3SD of the OD readings in the pre-COVID-19 control population. Most pre-COVID-19 controls

169 had only background reactivity for both the full-length $\mathrm{S}$ protein and $\mathrm{RBD}(\operatorname{IgG}=98.9 \%, \mathrm{n}=$

$170514 / 520$ and $98.5 \%, \mathrm{n}=512 / 520$ below established cut-off, respectively). Each antigen and

171 antibody class had a few pre-COVID-19 controls that tested positive for the antibodies based on

172 the determined cut-off. The majority of pre-COVID-19 controls that tested positive within the

173 groups had IgM against both $\mathrm{S}$ protein and RBD, $1.5 \%(\mathrm{n}=8 / 520$ testing antibody-positive $)$ and

$1742.1 \%(n=11 / 520$ antibody-positive), respectively. Some control samples were positive in the $\mathrm{S}$

175 protein- and RBD-specific IgA assays: $1.3 \%(\mathrm{n}=7 / 520$ antibody-positive $)$ and $1.0 \%(\mathrm{n}=5 / 520$

176 antibody-positive), respectively. Antigen concentration of S protein and RBD and serum

177 dilutions were optimized by testing known COVID-19-positive and pre-COVID-19 samples (see

178 Supplemental data).

179 Of the 153 resolved COVID-19 subjects tested, 131 (85.6\%) tested positive for antibodies

180 against SARS-CoV-2 (IgG, IgA, or IgM antibodies against the S protein or RBD, Table 2) and

$18122(14.4 \%)$ did not have detectable antibodies against SARS-CoV-2. Of the 55 RT-PCR-negative

182 subjects, three had reactivity to the SARS-CoV-2 antigens (5.5\%, Table 2). Most resolved

183 subjects tested positive for anti-S protein and anti-RBD IgG ( $\mathrm{n}=130 / 153$ testing positive (85.0\%)

184 and $n=119 / 153$ testing positive (77.8\%), respectively, Supplemental data). In addition, some of

185 the same resolved subjects also tested positive for anti-S protein IgA $(60.1 \%, 92 / 153$ antibody-

186 positive), anti-S protein $\operatorname{IgM}(35.3 \%, 54 / 153$ antibody-positive), and anti-RBD $\operatorname{IgA}(24.2 \%$,

$18737 / 153$ antibody-positive) and $\operatorname{IgM}(19.6 \%, 30 / 153$ antibody-positive).

188 High Ct counts found in resolved subjects who were SARS-CoV-2 antibody-negative 
medRxiv preprint doi: https://doi.org/10.1101/2020.09.11.20192690; this version posted March 11, 2021. The copyright holder for this preprint (which was not certified by peer review) is the author/funder, who has granted medRxiv a license to display the preprint in perpetuity.

It is made available under a CC-BY-NC-ND 4.0 International license .

To further understand RT-PCR-positive COVID-19 subjects that tested negative for anti-SARS-

190 CoV-2 antibodies, 22/153 (14.4\%) resolved subjects were further investigated. The Ct values

191 from the initial RT-PCR test were obtained for 54/153 (35.3\%) of the resolved participants,

192 including 18/22 (81.8\%) who were RT-PCR-positive but antibody-negative. The Ct values for

193 the RT-PCR-positive/antibody-negative subjects $(n=18)$ ranged from 16.00 to 37.38, with a

194 mean of $32.29 \pm 4.647$, whereas the mean of the subjects who were RT-PCR-positive/antibody-

195 positive was $22.92 \pm 5.177$ (range $=14.99-34.94$, n=36, Figure 1A, 1B). Sera from 13 of 18

196 resolved subjects who tested RT-PCR-positive/antibody-negative were collected within 60 days

197 after initial RT-PCR test, within the reported optimal time for anti-SARS-CoV-2 antibodies

198 (Figure 1C) $[18,20,21,26]$.

199 During assay validation, 14 resolved subjects (9 antibody-positive and 5 antibody-negative) were

200 tested in the commercially available EUROIMMUN Anti-SARS-CoV-2 ELISA and the Ortho

201 Clinical Diagnostics COVID-19 IgG Antibody Test. There was 100\% correlation between the

202 commercial reference assays and our in-house developed assays. Three of the 14 in validation

203 testing were RT-PCR-positive/antibody-negative and had high Ct value samples and were

204 confirmed to be negative for SARS-CoV-2 antibodies in the commercial reference assays

205 (Supplemental data).

Persistence of anti-S protein and anti-RBD antibodies in resolved subjects

207 IgG antibodies against S protein and RBD were detected in samples collected $>120$ days from

208 symptom onset (Figure 2A)[5, 16, 18, 20]. Anti-S protein IgG was found in all resolved

209 participants collected between 60 and 120 days (23/153 resolved subjects). In the resolved

210 patients collected between 120 and 180 days from symptom onset, there was a decrease in the

211 percentage of antibody-positive samples when compared to the previous time bin (55/60 
medRxiv preprint doi: https://doi.org/10.1101/2020.09.11.20192690; this version posted March 11, 2021. The copyright holder for this preprint (which was not certified by peer review) is the author/funder, who has granted medRxiv a license to display the preprint in perpetuity.

It is made available under a CC-BY-NC-ND 4.0 International license .

212 samples, 91.7\%). Of the resolved subjects tested $>180$ days of symptom onset $(\mathrm{n}=11), 90.9 \%$ had

213 an anti-S protein IgG antibody. However, IgG levels against RBD demonstrated a 14.8\%

214 decrease in subjects who were antibody-positive between 120-180 days when compared to the

215 groups before 120 days, and a 30\% decrease in subjects with antibody after 180 days (Figure

$2162 \mathrm{~A})$. In contrast, $\operatorname{IgA}$ and $\operatorname{IgM}$ to both antigens were much less sustained (IgA - Figure $2 \mathrm{~B}, \operatorname{IgM}$

217 - Figure 2C). After reaching a maximum in the 0-60 days bin, there was a clear and continuous

218 decline throughout the time series such that after 180 days, the anti-S protein and anti-RBD IgA

219 levels in subject groups declined by $30 \%$ and $80 \%$ respectively, while IgM levels for both

220 antigens declined by $90 \%$ (IgA - Figure 2B, IgM - Figure 2C).

221

Investigation of neutralizing SARS-CoV-2 antibodies

222 Neutralization potency was measured using a microneutralization assay with live SARS-CoV-2

223 virus. In all resolved subjects, the presence of high titers of anti-S protein and anti-RBD IgG

224 moderately correlated with higher titers of neutralizing antibodies (Figure 3A, 3B, r=0.5157,

$225 \mathrm{p}<0.0001$ anti-S protein $\operatorname{IgG}$ and $\mathrm{r}=0.601, \mathrm{p}<0.0001$ anti-RBD IgG). Weaker correlations were

226 found between neutralizing antibody titers and anti-S protein $\operatorname{IgA}(\mathrm{r}=0.4507), \operatorname{IgM}(\mathrm{r}=0.4443)$,

227 and anti-RBD $\operatorname{IgA}(\mathrm{r}=0.3055), \operatorname{IgM}(\mathrm{r}=0.3365)$. Geometric MNT50s ranged from below

228 detection limit (MNT50 = 5) to MNT50=1280. Resolved subjects who were only antibody-

229 positive for anti-S protein IgG but not antibody-positive for anti-RBD IgG antibodies $(\mathrm{n}=11)$

230 either had lower neutralizing antibody levels (mean MNT50 $=19.5$, range 5 - 80) or were

231 undetectable. No temporal trends were observed based on this cross-sectional study of resolved

232 subjects, however neutralizing antibodies in resolved subjects were detected as far as 180 days

233 post-symptom onset (Figure 3C). After 180 days, 3/11 (27.3\%) of subjects tested for neutralizing

234 antibodies had a level above MNT50=160. 
medRxiv preprint doi: https://doi.org/10.1101/2020.09.11.20192690; this version posted March 11, 2021. The copyright holder for this preprint (which was not certified by peer review) is the author/funder, who has granted medRxiv a license to display the preprint in perpetuity.

It is made available under a CC-BY-NC-ND 4.0 International license .

SARS-CoV-2 antibody profile of asymptomatic, non-hospitalized, and hospitalized resolved subjects

237 Of the 153 resolved subjects tested, eight (5.2\%) were hospitalized for SARS-CoV-2 infection

238 and were positive for anti-SARS-CoV-2 antibodies. All hospitalized subjects had detectable anti-

239 RBD and anti-S protein IgG, and anti-S protein IgA antibodies in their serum (Figure 4A and

240 4B). The levels of anti-S protein and anti-RBD IgG (mean OD 405 ratio) in resolved subjects who

241 were hospitalized were significantly higher than the non-hospitalized resolved population (anti-S

242 protein $\mathrm{IgG} ; 5.667 \pm 0.065$ vs. $3.836 \pm 1.831$, p<0.001; anti-RBD IgG 5.240 \pm 0.8483 vs.

$2432.758 \pm 1.730, \mathrm{p}<0.001)$. All other antigen and antibody classes were not significantly different

244 between hospitalized and non-hospitalized resolved subjects. When compared to resolved

245 hospitalized subjects (range: 3.209 - 5.831), there was a larger spread in antibody levels in the

246 non-hospitalized population (range: 0.1508 - 5.828; Figure 4).

247 Of the resolved COVID-19 study participants collected, $11(7.2 \%)$ were asymptomatic. Six of

248 the $11(54.5 \%)$ asymptomatic subjects did not produce any anti-S protein or anti-RBD antibodies

249 (Figure 4). Six of the asymptomatic subjects were in the category of RT-PCR-positive/antibody-

250 negative with a high $\mathrm{Ct}$ value.

252 Discussion:

253 Understanding the characteristics of the SARS-CoV-2 antibodies will inform on the

254 seroprevalence in communities and portions of the COVID-19 immune response. We describe

255 initial cross-sectional results of our longitudinal study of quantitative and functional SARS-CoV-

2562 antibodies in resolved subjects. The expression of $\operatorname{IgG}, \operatorname{IgA}$ and $\operatorname{IgM}$ antibodies reactive to the

257 immunogenic S protein and the RBD varied based on infection of SARS-CoV-2, severity of the 
medRxiv preprint doi: https://doi.org/10.1101/2020.09.11.20192690; this version posted March 11, 2021. The copyright holder for this preprint (which was not certified by peer review) is the author/funder, who has granted medRxiv a license to display the preprint in perpetuity.

It is made available under a CC-BY-NC-ND 4.0 International license.

disease, and time delay from onset of symptoms to blood draw. We also observed temporal and functional differences in anti-SARS-CoV-2 antibodies based on Ig classes and antigen.

Antibodies to SARS-CoV-2 were found in 131/153 (85.6\%) subjects who tested positive in the RT-PCR. In 22 of 153 (14.4\%) resolved subjects who tested RT-PCR-positive, no antibodies against SARS-CoV-2 were detected, which prompted further investigation using $\mathrm{Ct}$ values. Of 18 samples of whom Ct values were available, 17 had high Ct values (32.29 \pm 4.647 , range $=16.00$ to 37.38 , Figure $1 \mathrm{D})$. The variation in antibody response in RT-PCR-positive subjects may be due to multiple contributing factors including the size of the viral inoculum, the genetic background of patients, and the presence of concomitant pathological conditions [27].

Studies have reported that after COVID-19 infection in some subjects, no antibodies can be detected in circulation either because they have waned quickly, or that their immune response is dependent on T cell responses [28-30]. Another factor is disease severity in the detection of SARS-CoV-2 antibodies. Strong neutralizing antibody responses may require more extensive affinity maturation, which is detected more in COVID-19 patients with severe disease symptoms $[27,31,32]$. Therefore, it is possible that the inability to detect antibodies in RT-PCR-positive subjects may be due to an infection insufficient of magnitude or durability [33]. Another possibility can be that the RT-PCR-positive/antibody-negative subjects had high Ct values at the limit of detection for the assay and did not actually contract the SARS-CoV-2 virus. One study showed there is reduced probability of cultivable viral cultures from samples with a $\mathrm{Ct}>24$ or when samples are obtained $>8$ days after symptom onset [34], and another study showed $\mathrm{Ct}$ values above 33-34 were not associated with cell culture viral recovery [35]. The developed ELISA for all Ig classes against S protein and RBD antigens has a sensitivity of $97.1 \%$ after removal of these 17 subjects with indeterminate test results from analysis. 
medRxiv preprint doi: https://doi.org/10.1101/2020.09.11.20192690; this version posted March 11, 2021. The copyright holder for this preprint (which was not certified by peer review) is the author/funder, who has granted medRxiv a license to display the preprint in perpetuity.

It is made available under a CC-BY-NC-ND 4.0 International license.

Two subjects enrolled in this study were categorized as RT-PCR-negative based on a second RT-PCR test. Their initial RT-PCR test was positive, but retested RT-PCR-negative within 1-2 days after the first result due to the initial test having a high $\mathrm{Ct}$ value positive result

284 without any symptoms or contact history. It is possible that some of the RT-PCR-

285 positive/antibody-negative subjects with high $\mathrm{Ct}$ values, would have tested negative in a repeated

286 RT-PCR test as well. A study showing repeat testing of the same subjects describes $6.8 \%$ of

287 participants who initially test positive, tested negative in a follow-up RT-PCR test [36].

288 Repeating tests can reduce false-positive results, especially in those who have minimal indicators 289 for having been infected. Another way to distinguish possible false-positive results in the RT-

290 PCR is to use a combination of RT-PCR testing and antibody testing to improve the accuracy of

291 COVID-19 diagnosis. One study utilizing rapid antigen diagnostic tests in combination with

$292 \operatorname{IgM/IgG~detection,~identified~more~subjects~with~COVID-19~admitted~in~an~emergency~}$

293 department than when the assays are performed separately [37].

295 who tested RT-PCR-negative. Detection of SARS-CoV-2 antibodies in these samples may be a

296 result of cross-reactivity of the antibodies with seasonal coronaviruses from previous infections

$297[38,39]$. In the pre-COVID-19 samples $(n=520), 11(2.1 \%)$ had cross-reactivity to the SARS-

298 CoV-2 antigens. Additionally, one of the three subjects who was RT-PCR-negative and positive

299 for SARS-CoV-2 antibody was tested in the RT-PCR 113 days after initial symptom onset,

300 which is later than the optimal timing since symptom onset for RT-PCR testing, possibly being

301 the reason for a false-negative RT-PCR test. Taking into account the RT-PCR-negative cohort of 302 subjects, we calculate the overall specificity of the in-house ELISA to be $96.7 \%$. 
medRxiv preprint doi: https://doi.org/10.1101/2020.09.11.20192690; this version posted March 11, 2021. The copyright holder for this preprint (which was not certified by peer review) is the author/funder, who has granted medRxiv a license to display the preprint in perpetuity.

It is made available under a CC-BY-NC-ND 4.0 International license .

Antibody kinetics reported previously in SARS-CoV-2 infected subjects suggest that titers of the virus-specific $\operatorname{IgG}$ and $\operatorname{IgM}$ antibodies increase 21 days post symptom onset $[18,40]$. However, other studies indicate conflicting evidence on whether IgG and neutralizing antibody levels persist or begin to decline in a high proportion of recovered subjects within 2-3 months

307 after infection [18]. Our study found that IgM positivity was lower than that of IgG after

308 infection $[18,38,41,42]$. Minimal differences were also observed in the percentage of anti-S

309 protein and anti-RBD present in participants drawn at various times over a 3-month period.

310 Furthermore, anti-SARS-CoV-2 antibodies could be found in the circulation of some resolved 311 subjects 200 days post-symptom onset. Resolved subjects who were asymptomatic but RT-PCR-

312 positive, had the lowest titre of SARS-CoV-2 antibodies.

314 able to determine the functional inhibitory capacity of antibodies against all antigens of SARS-

315 CoV-2. Neutralizing antibody titres have recently been shown to wane fairly rapidly in some 316 studies and levels were found to be variable in recovered subjects [19, 21, 43-45]. The U.S. Food

317 and Drug Administration (FDA) recommends that the titer of neutralizing antibodies in

318 convalescent plasma should be at least 1/160, but a 1/80 titer is acceptable in the absence of a

319 better match for use in convalescent plasma therapy [46]. Most resolved COVID-19 subjects

320 were found to have developed levels of SARS-CoV-2-specific neutralizing antibodies similar to

321 other cross-sectional studies [19, 44, 45]. Neutralizing SARS-CoV-2 antibodies correlated best

322 with a positive anti-RBD $\operatorname{IgG}(r=0.5157)$ and anti-S protein $\operatorname{IgG}$ antibody $(r=0.6010)$ result.

323 However, at this time we do not know what relevant thresholds of neutralizing antibodies confer

324 protection from infection. Of interest, it has been shown that although Fc-dependent effector

325 functions are required for optimal protection, these are often mediated by non-neutralizing 
medRxiv preprint doi: https://doi.org/10.1101/2020.09.11.20192690; this version posted March 11, 2021. The copyright holder for this preprint (which was not certified by peer review) is the author/funder, who has granted medRxiv a license to display the preprint in perpetuity.

It is made available under a CC-BY-NC-ND 4.0 International license .

326 antibodies [47]. Neutralization assays are performed with serum, and thus it is not possible to

327 define the relative contribution of each antibody class to neutralizing activity.

This study has limitations. Recall bias of dates and symptoms by the study participants

329 may affect the interpretation of timing of virus detection in relation to symptom onset. For

330 asymptomatic cases, the time when infection was acquired is not known. In conclusion, our

331 study suggests that there is a variable antibody response in resolved subjects and a variable

332 reduction in antibody positivity over time. The negative antibody results found in the SARS-

333 CoV-2 ELISA in RT-PCR-positive samples may suggest a varied immune response that warrants

334 further studies. Although serologic tests cannot be used as the primary diagnostic test, they may

335 be used to support diagnosis of COVID-19 for persons who are tested later, outside the optimal

336 RT-PCR window. The resolved subjects collected for this study are part of a larger longitudinal

337 study that will provide further insight on antibody prevalence over time. Further studies with this

338 longitudinal cohort will be critical in characterizing the nature and kinetics of SARS-CoV-2

339 antibodies and their ability to confer long-term immunity. 
medRxiv preprint doi: https://doi.org/10.1101/2020.09.11.20192690; this version posted March 11, 2021. The copyright holder for this preprint (which was not certified by peer review) is the author/funder, who has granted medRxiv a license to display the preprint in perpetuity.

It is made available under a CC-BY-NC-ND 4.0 International license .

\section{Acknowledgements:}

342 We thank Erjona Kruja for technical assistance. Funding support for this work was provided by

343 grants from the Ontario Research Fund (ORF), COVID-19 Rapid Research Fund (\#C-191-

344 2426729-NAZY) and by the Canadian Institute of Health Research (CIHR)-COVID-19

345 Immunity Task Force (CITF; \#VR2-173204) awarded to Dr. Ishac Nazy, and Academic Health

346 Sciences Organization (HAHSO) grant awarded to Dr. Donald M. Arnold (\#HAH-21-02). This

347 work was also supported, in part, by a Weston Family Microbiome Initiative Grant and a

348 Canadian Institute of Health Research (CIHR) COVID-19 Rapid Response grant to Dr. Matthew

349 S. Miller. Dr. Miller was also supported, in part, by a CIHR New Investigator Award and an

350 Ontario Early Researcher Award. Ali Zhang is supported by a PSI Research Trainee Fellowship

351 and a CIHR Canada Graduate Scholarships - Doctoral Award. Hannah D. Stacey was supported

352 in part by an Ontario Graduate Scholarship.

353 Cell Lines:

354 SARS-CoV-2/SB3-TYAGNC strain information: https://wwwnc.cdc.gov/eid/article/26/9/20-

355 1495_article

356 Authorship Contributions:

357 AH carried out the described studies, analyzed data, and wrote the manuscript. DMA designed

358 the research and helped write the manuscript. JWS and AZ carried out the described studies, 359 analyzed data, and wrote the manuscript. JCM assisted with experimentation, provided technical 360 assistance, and helped write the manuscript. VTC provided technical assistance. HDS and JCA

361 provided technical assistance and materials. ZC, BJH, RC, NI, DMEB, MSM, and JGK designed 
medRxiv preprint doi: https://doi.org/10.1101/2020.09.11.20192690; this version posted March 11, 2021. The copyright holder for this preprint (which was not certified by peer review) is the author/funder, who has granted medRxiv a license to display the preprint in perpetuity. It is made available under a CC-BY-NC-ND 4.0 International license.

362 the research and helped write the manuscript. IN designed the research, interpreted data and 363 wrote the manuscript. All authors reviewed and approved the final version of the manuscript.

\section{Disclosure of Conflicts of Interest:}

366 The authors declare no competing financial interests. 
medRxiv preprint doi: https://doi.org/10.1101/2020.09.11.20192690; this version posted March 11, 2021. The copyright holder for this preprint (which was not certified by peer review) is the author/funder, who has granted medRxiv a license to display the preprint in perpetuity. It is made available under a CC-BY-NC-ND 4.0 International license.

367 Figures and Tables:

368 Table 1: Clinical Characteristics of Study Participants

\begin{tabular}{ccc}
$\begin{array}{c}\text { Pre-COVID-19 } \\
\text { controls }\end{array}$ & Resolved & RT-PCR- \\
COVID-19 & negative \\
$(\mathbf{n}=\mathbf{5 2 0})$ & subjects & subjects \\
& $(\mathbf{n}=\mathbf{1 5 3})$ & $(\mathbf{n}=\mathbf{5 5})$ \\
\hline- & 18 to 82 & 20 to 89 \\
& & $($ median=49)
\end{tabular}

\section{Gender}

Male (\%)

Female $(\%)$ $\begin{array}{ll}- & 58(37.9)\end{array}$

$95(62.1)$
$145(94.8)$

$8(5.2)$

Hospitalized (\%)

Sample Collection Dates

SARS-CoV-2 RT-PCR positivity

Negative
$-$

$-$

\section{SARS-CoV-2 RT-PCR positivity}

\author{
Positive
}

\section{Hospitalization Status}

Never hospitalized (\%)

\begin{tabular}{lcc}
\hline Ages (years) & 18 to 82 & 20 to 89 \\
& $($ median=49) & $($ median=49)
\end{tabular}


medRxiv preprint doi: https://doi.org/10.1101/2020.09.11.20192690; this version posted March 11, 2021. The copyright holder for this preprint (which was not certified by peer review) is the author/funder, who has granted medRxiv a license to display the preprint in perpetuity. It is made available under a CC-BY-NC-ND 4.0 International license.

Symptomatic $(\%)$

Asymptomatic (\%)
$-$

$-$
$142(92.8)$

$11(7.2)$

$($ median=130.5 $) \quad($ median=141.5)
$37(67.3)$

$18(32.7)$

$7-260$
Days post-symptom onset at collection (days)
$19-227$

$-$

$($ median=130.5)


medRxiv preprint doi: https://doi.org/10.1101/2020.09.11.20192690; this version posted March 11, 2021. The copyright holder for this preprint (which was not certified by peer review) is the author/funder, who has granted medRxiv a license to display the preprint in perpetuity. It is made available under a CC-BY-NC-ND 4.0 International license.

371 Table 2: Cross-sectional analysis of RT-PCR and SARS-CoV-2 Antibody Testing

\section{RT-PCR-positive RT-PCR-negative}

(Resolved, $\mathbf{n}=\mathbf{1 5 3}) \quad(\mathrm{n}=55)$
SARS-CoV-2

Antibody positive (\%)

SARS-CoV-2

Antibody negative (\%)
$131 / 153$

85.6

$22 / 153$

$52 / 55$

14.4

94.5 

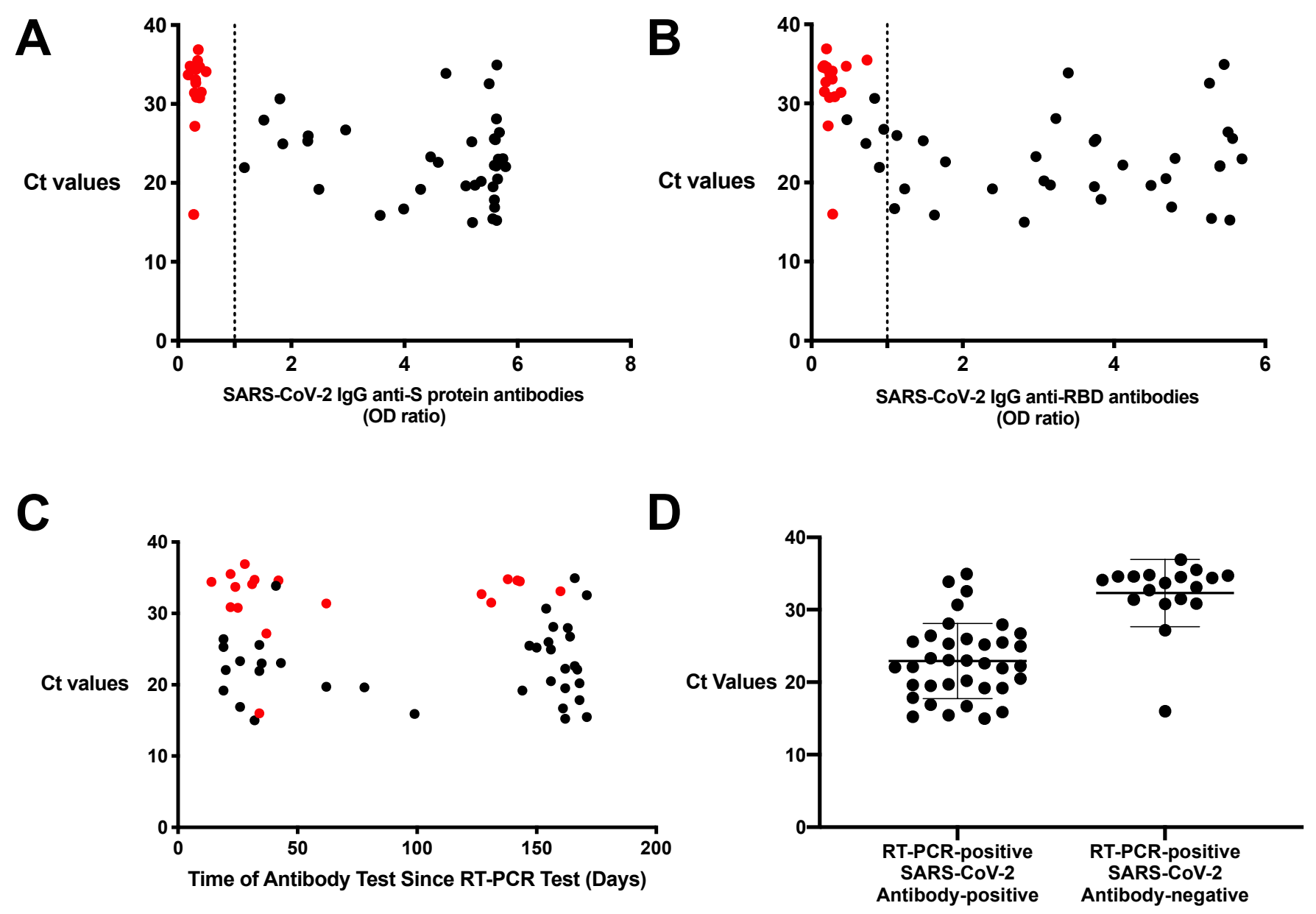

377 Figure 1: Ct values are variable in resolved subjects who test SARS-CoV-2 antibody negative or

378 positive. $\mathrm{Ct}$ values of a subset of resolved subjects $(\mathrm{n}=54)$ were compared to their corresponding

379 SARS-CoV-2 (A) anti-S protein IgG and (B) anti-RBD IgG. (C) Ct values were then compared to

380 the subjects' respective time since initial RT-PCR test. (D) Ct values for RT-PCR-positive in

381 antibody-positive and antibody-negative were compared. Values are shown as a ratio of observed

382 optical density to the determined assay cut-off optical density or time since RT-PCR test until

383 blood donation compared to absolute Ct values. Red circles indicate resolved samples who were

384 RT-PCR-positive/antibody-negative. 
medRxiv preprint doi: https://doi.org/10.1101/2020.09.11.20192690; this version posted March 11, 2021. The copyright holder for this preprint (which was not certified by peer review) is the author/funder, who has granted medRxiv a license to display the preprint in perpetuity.

It is made available under a CC-BY-NC-ND 4.0 International license .

A

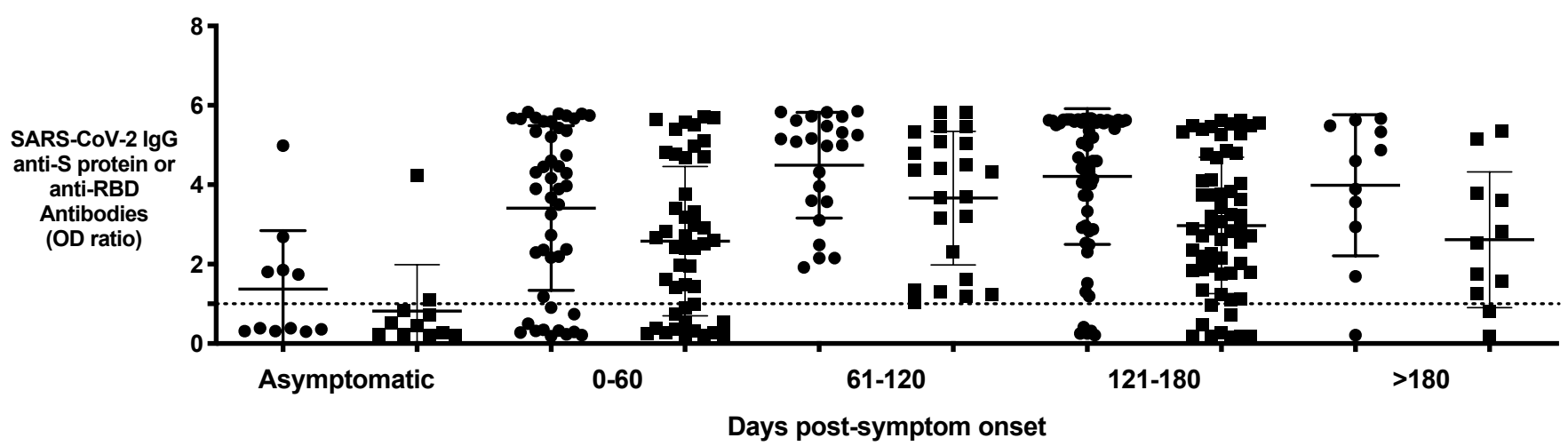

B

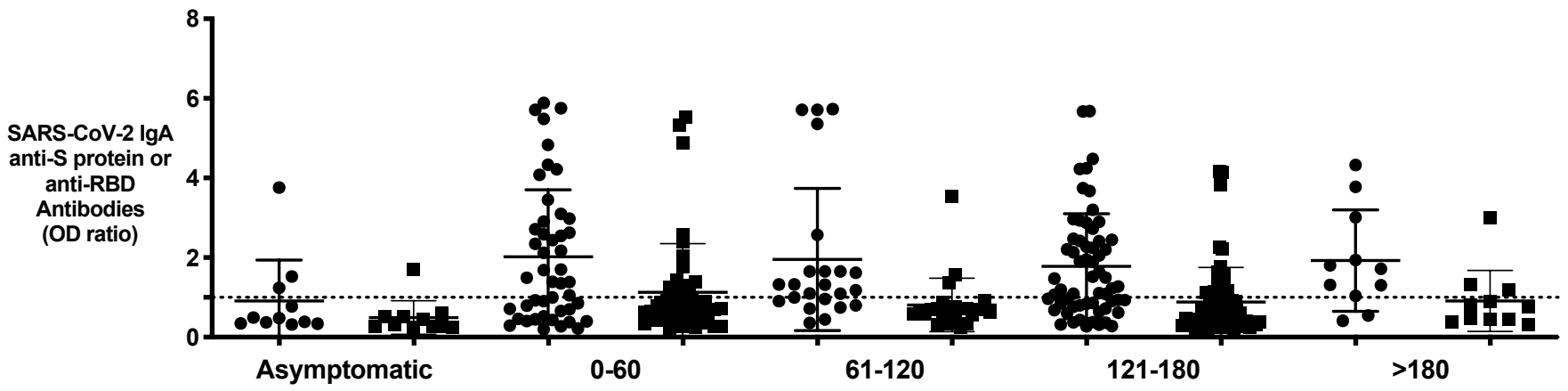

Days post-symptom onset

C

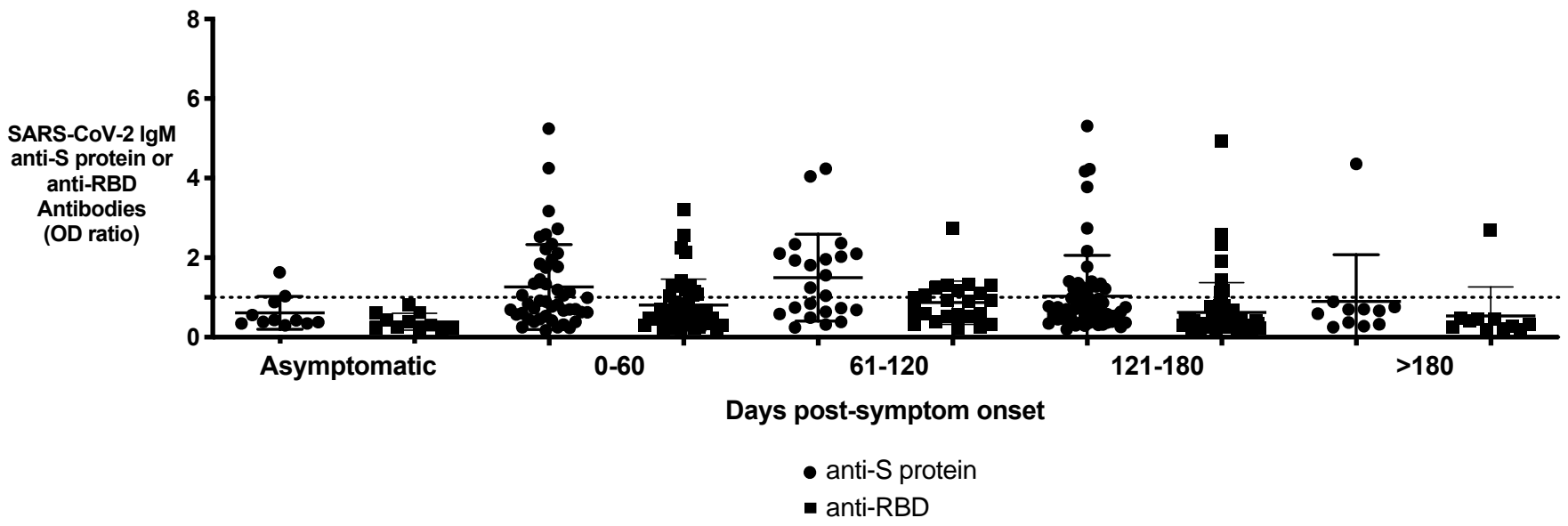

387 collection post-symptom onset. Resolved subjects $(\mathrm{n}=153)$ were grouped based on days post-

388 symptom onset showing levels of (A) anti-S protein and anti-RBD IgG, (B) $\operatorname{IgA}$, and (C) $\operatorname{IgM}$

389 displayed as dot plots. Days post-symptom onset are binned in 60-day increments and are

390 compared to asymptomatic resolved subjects. Circles represent anti-S protein antibodies and 
medRxiv preprint doi: https://doi.org/10.1101/2020.09.11.20192690; this version posted March 11, 2021. The copyright holder for this preprint (which was not certified by peer review) is the author/funder, who has granted medRxiv a license to display the preprint in perpetuity. It is made available under a CC-BY-NC-ND 4.0 International license.

391 squares represent anti-RBD antibodies. Anti-S protein $\mathrm{IgG}$ was found in all resolved participants

392 collected between 60 and 120 days ( 23 of 153 total resolved subjects). In the resolved patients

393 collected between 120 and 180 days from symptom onset, there was a decrease in the percentage

394 of antibody-positive samples when compared to the previous time bin (55 of 60 samples, $91.7 \%$ ). 
medRxiv preprint doi: https://doi.org/10.1101/2020.09.11.20192690; this version posted March 11, 2021. The copyright holder for this preprint (which was not certified by peer review) is the author/funder, who has granted medRxiv a license to display the preprint in perpetuity.

It is made available under a CC-BY-NC-ND 4.0 International license.
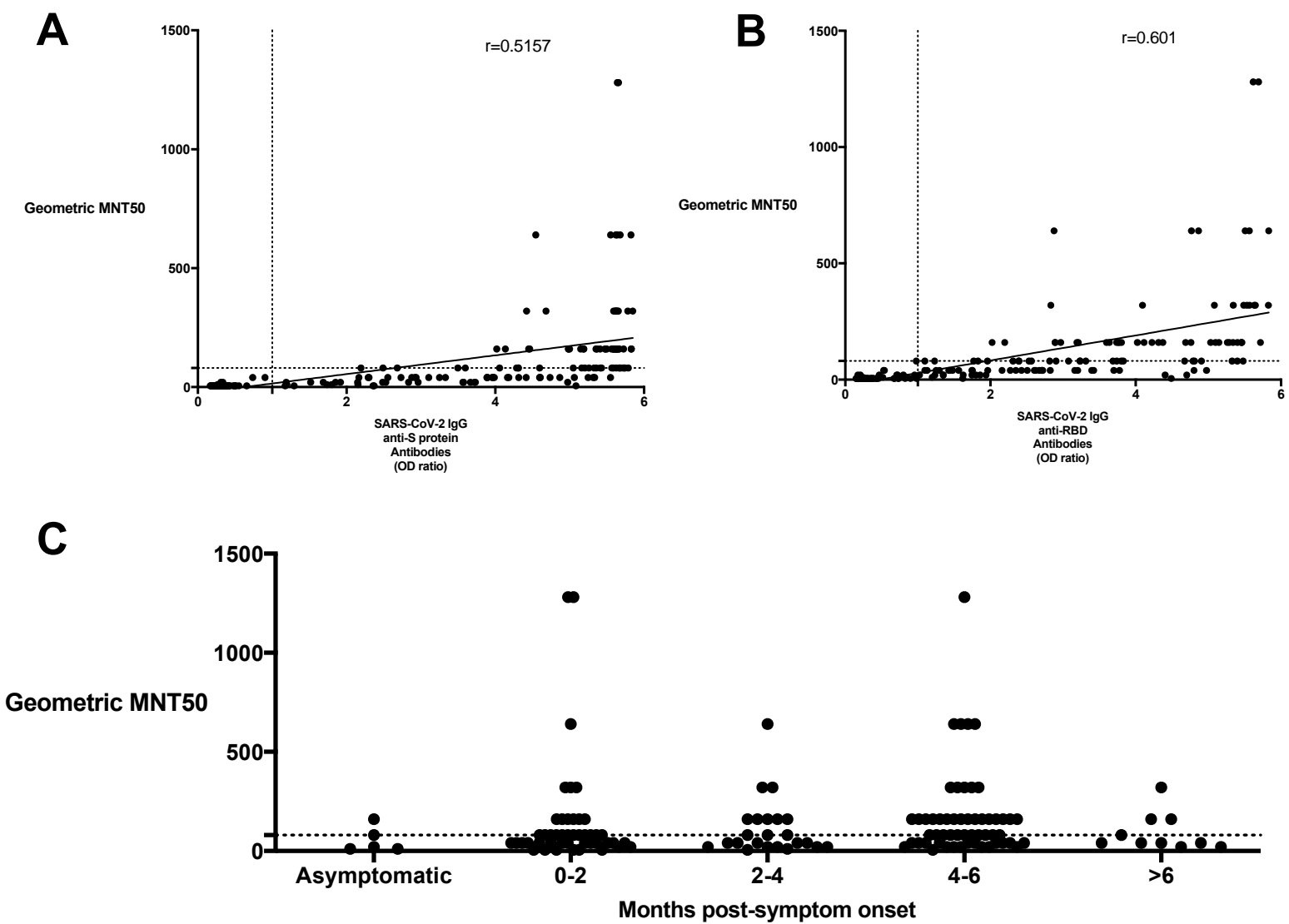

\begin{tabular}{lccc}
\hline Level of & Asymptomatic & Non-hospitalized & Hospitalized \\
Neutralization & $(\mathbf{n = 1 1})$ & $(\mathbf{n = 1 3 4})$ & $(\mathbf{n}=\mathbf{8})$ \\
\hline Undetectable & $6 / 11$ & $(14.9 \%)$ & \\
\hline Below Suggested & $(54.5 \%)$ & $50 / 134$ & 0 \\
FDA Level & $3 / 11$ & $(37.3 \%)$ & $8 / 8$ \\
Above Suggested & $(27.3 \%)$ & $64 / 134$ & $(100 \%)$ \\
FDA Level & $2 / 11$ & $(47.8 \%)$ & \\
\hline
\end{tabular}


medRxiv preprint doi: https://doi.org/10.1101/2020.09.11.20192690; this version posted March 11, 2021. The copyright holder for this preprint (which was not certified by peer review) is the author/funder, who has granted medRxiv a license to display the preprint in perpetuity.

It is made available under a CC-BY-NC-ND 4.0 International license .

399 Figure 3: Neutralizing SARS-CoV-2 antibodies against S protein and RBD in IgG, IgA, and

$400 \quad$ IgM found in variable levels in resolved and RT-PCR-negative study participants. Neutralizing

401 SARS-CoV-2 antibody titers from resolved subjects $(n=153)$ were measured in the

402 microneutralization assay and compared to (A) anti-S protein and (B) anti-RBD IgG antibody

403 levels as measured in the SARS-CoV-2 ELISA. Neutralizing antibody titers are expressed as

404 geometric MNT50 values (y-axis). ELISA values are shown as a ratio of observed optical density

405 to the determined assay cut-off optical density (x-axis). (C) Neutralizing SARS-CoV-2 antibody

406 titers from resolved subjects $(n=153)$ were measured in the microneutralization assay were

407 compared to their days since symptom onset. Values above 1 ratio are considered positive in the

408 SARS-CoV-2 ELISA.

409

410 
medRxiv preprint doi: https://doi.org/10.1101/2020.09.11.20192690; this version posted March 11, 2021. The copyright holder for this preprint (which was not certified by peer review) is the author/funder, who has granted medRxiv a license to display the preprint in perpetuity.

$\mathbf{A}$

B

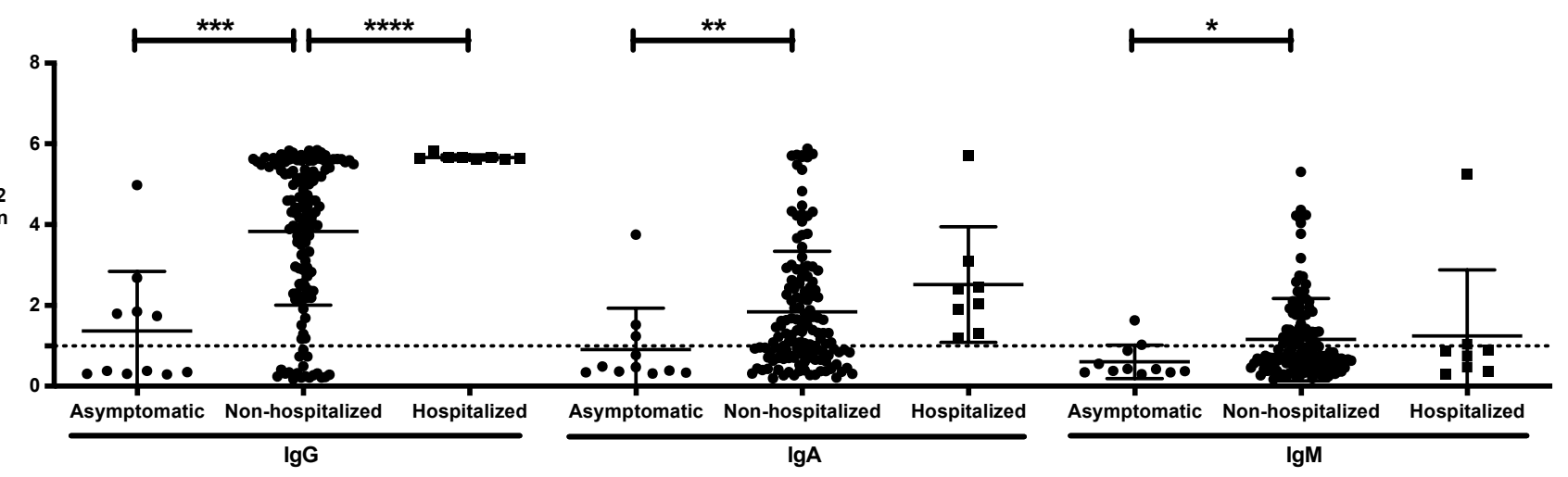

B
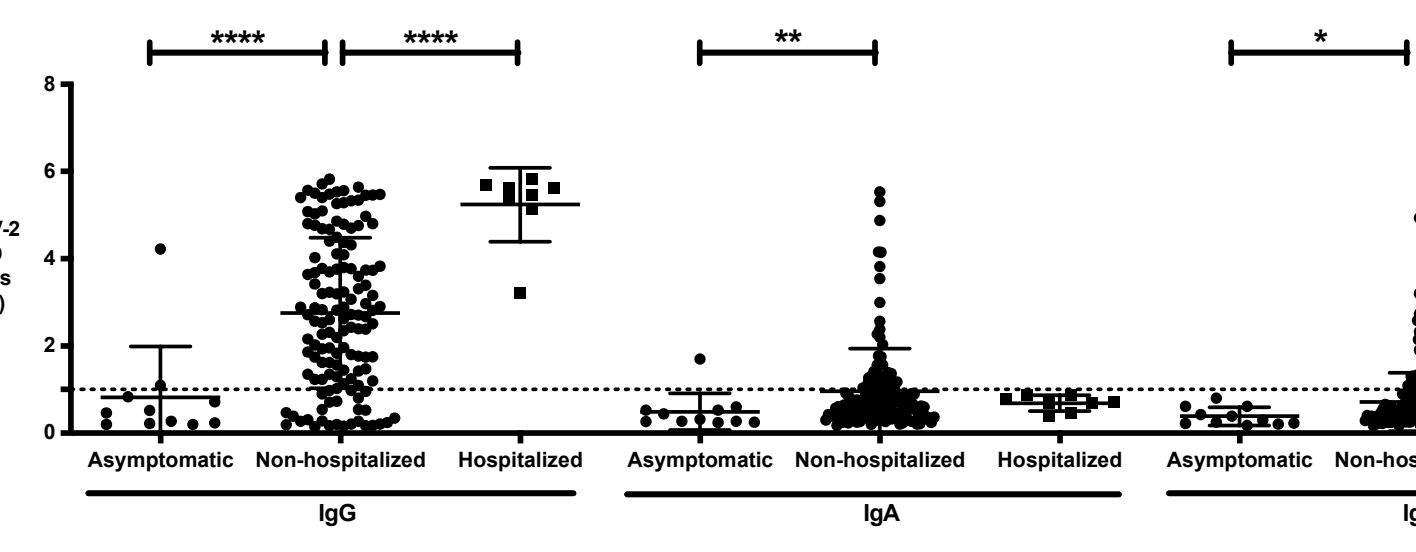

413 antigens in asymptomatic, non-hospitalized and hospitalized resolved subjects. (A) Anti-S

414 protein $\operatorname{IgG}, \operatorname{Ig} A$, IgM and (B) anti-RBD $\operatorname{IgG}, \operatorname{IgA}$, and $\operatorname{IgM}$ of the asymptomatic (n=11), non-

415 hospitalized resolved subjects $(n=134)$ and hospitalized resolved subjects $(n=8)$ were profiled

416 using the SARS-CoV-2 ELISA. Values are shown as a ratio of observed optical density to the

417 determined assay cut-off optical density. All hospitalized subjects had detectable anti-S protein

418 IgG, anti-RBD IgG and anti-S protein IgA antibodies in their serum. The levels of anti-S protein

419 and anti-RBD IgG (mean OD405 ratio) in resolved subjects who were hospitalized were 
medRxiv preprint doi: https://doi.org/10.1101/2020.09.11.20192690; this version posted March 11, 2021. The copyright holder for this preprint (which was not certified by peer review) is the author/funder, who has granted medRxiv a license to display the preprint in perpetuity. It is made available under a CC-BY-NC-ND 4.0 International license.

420 significantly higher than the non-hospitalized resolved population. Values above 1 ratio are

421 considered positive in the SARS-CoV-2 ELISA. * $p<0.05, * * p<0.01, * * * p<0.001, * * * * p<0.0005$ 
medRxiv preprint doi: https://doi.org/10.1101/2020.09.11.20192690; this version posted March 11, 2021. The copyright holder for this preprint (which was not certified by peer review) is the author/funder, who has granted medRxiv a license to display the preprint in perpetuity.

It is made available under a CC-BY-NC-ND 4.0 International license .

\section{References:}

424 1. Zhou P, Yang XL, Wang XG, et al. A pneumonia outbreak associated with a new coronavirus 425 of probable bat origin. Nature 2020; 579:270-3.

426 2. He X, Lau EHY, Wu P, et al. Temporal dynamics in viral shedding and transmissibility of

427 COVID-19. Nat Med 2020; 26:672-5.

428 3. Anderson RM, Heesterbeek H, Klinkenberg D, Hollingsworth TD. How will country-based

429 mitigation measures influence the course of the COVID-19 epidemic? The Lancet 2020;

$430 \quad 395: 931-4$

431 4. Mizumoto K, Kagaya K, Zarebski A, Chowell G. Estimating the asymptomatic proportion of

432 coronavirus disease 2019 (COVID-19) cases on board the Diamond Princess cruise ship,

433 Yokohama, Japan, 2020. Euro Surveill 2020; 25.

434 5. Gudbjartsson DF, Helgason A, Jonsson H, et al. Spread of SARS-CoV-2 in the Icelandic

435 Population. N Engl J Med 2020; 382:2302-15.

436 6. Tabata S, Imai K, Kawano S, et al. Clinical characteristics of COVID-19 in 104 people with

437 SARS-CoV-2 infection on the Diamond Princess cruise ship: a retrospective analysis. The

438 Lancet Infectious Diseases 2020.

439 7. Verity R, Okell LC, Dorigatti I, et al. Estimates of the severity of coronavirus disease 2019: a

440 model-based analysis. The Lancet Infectious Diseases 2020; 20:669-77.

441 8. He JL, Luo L, Luo ZD, et al. Diagnostic performance between CT and initial real-time RT-

442 PCR for clinically suspected 2019 coronavirus disease (COVID-19) patients outside Wuhan,

443 China. Respir Med 2020; 168:105980.

444 9. Sethuraman N, Jeremiah SS, Ryo A. Interpreting Diagnostic Tests for SARS-CoV-2. JAMA

4452020. 
medRxiv preprint doi: https://doi.org/10.1101/2020.09.11.20192690; this version posted March 11, 2021. The copyright holder for this preprint (which was not certified by peer review) is the author/funder, who has granted medRxiv a license to display the preprint in perpetuity.

It is made available under a CC-BY-NC-ND 4.0 International license .

446 10. Chu DKW, Pan Y, Cheng SMS, et al. Molecular Diagnosis of a Novel Coronavirus (2019-

447 nCoV) Causing an Outbreak of Pneumonia. Clin Chem 2020; 66:549-55.

448 11. Corman VM, Landt O, Kaiser M, et al. Detection of 2019 novel coronavirus (2019-nCoV) by

449 real-time RT-PCR. Euro Surveill 2020; 25.

450 12. Letko M, Marzi A, Munster V. Functional assessment of cell entry and receptor usage for

451 SARS-CoV-2 and other lineage B betacoronaviruses. Nat Microbiol 2020; 5:562-9.

452 13. Wrapp D, Wang N, Corbett KS, et al. Cryo-EM structure of the 2019-nCoV spike in the

453 prefusion conformation. Science 2020; 367:1260-3.

454 14. Walls AC, Park YJ, Tortorici MA, Wall A, McGuire AT, Veesler D. Structure, Function, and

455 Antigenicity of the SARS-CoV-2 Spike Glycoprotein. Cell 2020; 181:281-92 e6.

456 15. Berry JD, Hay K, Rini JM, et al. Neutralizing epitopes of the SARS-CoV S-protein cluster

457 independent of repertoire, antigen structure or mAb technology. MAbs 2010; 2:53-66.

458 16. Amanat F, Stadlbauer D, Strohmeier S, et al. A serological assay to detect SARS-CoV-2

459 seroconversion in humans. Nat Med 2020.

460 17. Gorse GJ, Donovan MM, Patel GB. Antibodies to coronaviruses are higher in older

461 compared with younger adults and binding antibodies are more sensitive than neutralizing

462 antibodies in identifying coronavirus-associated illnesses. J Med Virol 2020; 92:512-7.

463 18. Long QX, Liu BZ, Deng HJ, et al. Antibody responses to SARS-CoV-2 in patients with

464 COVID-19. Nat Med 2020; 26:845-8.

465 19. Luchsinger LL, Ransegnola BP, Jin DK, et al. Serological Assays Estimate Highly Variable

466 SARS-CoV-2 Neutralizing Antibody Activity in Recovered COVID-19 Patients. J Clin

467 Microbiol 2020; 58. 
medRxiv preprint doi: https://doi.org/10.1101/2020.09.11.20192690; this version posted March 11, 2021. The copyright holder for this preprint (which was not certified by peer review) is the author/funder, who has granted medRxiv a license to display the preprint in perpetuity.

It is made available under a CC-BY-NC-ND 4.0 International license .

20. Okba NMA, Muller MA, Li W, et al. Severe Acute Respiratory Syndrome Coronavirus 2-

469 Specific Antibody Responses in Coronavirus Disease Patients. Emerg Infect Dis 2020; 26:1478-

47088

471 21. Prevost J, Gasser R, Beaudoin-Bussieres G, et al. Cross-Sectional Evaluation of Humoral

472 Responses against SARS-CoV-2 Spike. Cell Rep Med 2020; 1:100126.

473 22. Zhao J, Yuan Q, Wang H, et al. Antibody responses to SARS-CoV-2 in patients of novel 474 coronavirus disease 2019. Clin Infect Dis 2020.

475 23. Roost HP, Bachmann MF, Haag A, et al. Early high-affinity neutralizing anti-viral IgG

476 responses without further overall improvements of affinity. Proc Natl Acad Sci U S A 1995;

477 92:1257-61.

478 24. Chen Z, Zhang L, Qin C, et al. Recombinant modified vaccinia virus Ankara expressing the 479 spike glycoprotein of severe acute respiratory syndrome coronavirus induces protective 480 neutralizing antibodies primarily targeting the receptor binding region. J Virol 2005; 79:2678-88.

481 25. Stadlbauer D, Amanat F, Chromikova V, et al. SARS-CoV-2 Seroconversion in Humans: A

482 Detailed Protocol for a Serological Assay, Antigen Production, and Test Setup. Curr Protoc

483 Microbiol 2020; 57:e100.

484 26. Seow J, Graham C, Merrick B, et al. Longitudinal observation and decline of neutralizing 485 antibody responses in the three months following SARS-CoV-2 infection in humans. Nat

486 Microbiol 2020; 5:1598-607.

487 27. Chen X, Pan Z, Yue S, et al. Disease severity dictates SARS-CoV-2-specific neutralizing 488 antibody responses in COVID-19. Signal Transduct Target Ther 2020; 5:180. 
medRxiv preprint doi: https://doi.org/10.1101/2020.09.11.20192690; this version posted March 11, 2021. The copyright holder for this preprint (which was not certified by peer review) is the author/funder, who has granted medRxiv a license to display the preprint in perpetuity.

It is made available under a CC-BY-NC-ND 4.0 International license .

28. Peng Y, Mentzer AJ, Liu G, et al. Broad and strong memory CD4(+) and CD8(+) T cells

490 induced by SARS-CoV-2 in UK convalescent individuals following COVID-19. Nat Immunol

$491 \quad 2020 ; 21: 1336-45$.

492 29. Le Bert N, Tan AT, Kunasegaran K, et al. SARS-CoV-2-specific T cell immunity in cases of

493 COVID-19 and SARS, and uninfected controls. Nature 2020; 584:457-62.

494 30. Grifoni A, Weiskopf D, Ramirez SI, et al. Targets of T Cell Responses to SARS-CoV-2

495 Coronavirus in Humans with COVID-19 Disease and Unexposed Individuals. Cell 2020;

$496 \quad 181: 1489-501$ e15.

497 31. Schultheiss C, Paschold L, Simnica D, et al. Next-Generation Sequencing of T and B Cell

498 Receptor Repertoires from COVID-19 Patients Showed Signatures Associated with Severity of

499 Disease. Immunity 2020; 53:442-55 e4.

500 32. Marklund E, Leach S, Axelsson H, et al. Serum-IgG responses to SARS-CoV-2 after mild

501 and severe COVID-19 infection and analysis of IgG non-responders. PLoS One 2020;

$502 \quad 15: \mathrm{e} 0241104$.

503 33. Zhao J, Zhao J, Mangalam AK, et al. Airway Memory CD4(+) T Cells Mediate Protective

504 Immunity against Emerging Respiratory Coronaviruses. Immunity 2016; 44:1379-91.

505 34. Singanayagam A, Patel M, Charlett A, et al. Duration of infectiousness and correlation with

506 RT-PCR cycle threshold values in cases of COVID-19, England, January to May 2020. Euro

507 Surveill 2020; 25.

508 35. La Scola B, Le Bideau M, Andreani J, et al. Viral RNA load as determined by cell culture as

509 a management tool for discharge of SARS-CoV-2 patients from infectious disease wards. Eur J

510 Clin Microbiol Infect Dis 2020; 39:1059-61. 
medRxiv preprint doi: https://doi.org/10.1101/2020.09.11.20192690; this version posted March 11, 2021. The copyright holder for this preprint (which was not certified by peer review) is the author/funder, who has granted medRxiv a license to display the preprint in perpetuity.

It is made available under a CC-BY-NC-ND 4.0 International license .

511 36. Gniazdowski V, Morris CP, Wohl S, et al. Repeat COVID-19 Molecular Testing: Correlation

512 of SARS-CoV-2 Culture with Molecular Assays and Cycle Thresholds. Clin Infect Dis 2020.

513 37. Veyrenche N, Bollore K, Pisoni A, et al. 2020.

514 38. Adams ER, Ainsworth M, Anand R, et al. Antibody testing for COVID-19: A report from

515 the National COVID Scientific Advisory Panel. Wellcome Open Research 2020; 5.

516 39. Hicks J, Klumpp-Thomas C, Kalish H, et al. Serologic cross-reactivity of SARS-CoV-2 with

517 endemic and seasonal Betacoronaviruses. medRxiv 2020.

518 40. Duan K, Liu B, Li C, et al. Effectiveness of convalescent plasma therapy in severe COVID-

51919 patients. Proc Natl Acad Sci U S A 2020; 117:9490-6.

520 41. Gao HX, Li YN, Xu ZG, et al. Detection of serum immunoglobulin M and immunoglobulin

$521 \mathrm{G}$ antibodies in 2019 novel coronavirus infected patients from different stages. Chin Med J

522 (Engl) 2020; 133:1479-80.

523 42. Pérez-García F, Pérez-Tanoira R, Romanyk J, Arroyo T, Gómez-Herruz P, Cuadros-

524 González J. 2020.

525 43. Lee WT, Girardin RC, Dupuis Ii AP, et al. Neutralizing Antibody Responses in COVID-19

526 Convalescent Sera. J Infect Dis 2020.

527 44. Wu F, Liu M, Wang A, et al. Evaluating the Association of Clinical Characteristics With

528 Neutralizing Antibody Levels in Patients Who Have Recovered From Mild COVID-19 in

529 Shanghai, China. JAMA Intern Med 2020; 180:1356-62.

530 45. Muecksch F, Wise H, Batchelor B, et al. Longitudinal analysis of clinical serology assay

531 performance and neutralising antibody levels in COVID19 convalescents. medRxiv 2020.

532 46. (FDA) USFaDA. Investigational COVID-19 Convalescent Plasma. Guidance for Industry

5332020. 
medRxiv preprint doi: https://doi.org/10.1101/2020.09.11.20192690; this version posted March 11, 2021. The copyright holder for this preprint (which was not certified by peer review) is the author/funder, who has granted medRxiv a license to display the preprint in perpetuity.

534 47. Winkler ES, Gilchuk P, Yu J, et al. Human neutralizing antibodies against SARS-CoV-2

535 require intact Fc effector functions for optimal therapeutic protection. Cell 2021.

536 